\title{
Origin of the Eggon Centralized Traditional Chieftaincy Institution
}

\author{
David Umbugala*
}

\begin{abstract}
Culture is the totality of what a people are and what they believe. Any society, therefore, that undermines its culture touches the very soul of their existence. To this extent, culture must be invigorated from one generation to the other to avoid extinction. The Eggon nation from the beginning been endowed with very rich Mythical history but over the years, there have been a tendency to lose all of it at the altar of modernity. Several Scholars have made attempts to rediscover, express and promote the culture of the Eggon people as embodied in its language, customs and Costumes but in piecemeal or fragmented manner, which have not produced the desired intention. This effort is to harmonize together a document that will go a long way to provide the present and future generations specifically, a chronological history of 'The Origin of the Eggon Centralized Traditional Chieftaincy Institution'. This effort is also timely in view of the fact that many of our Older Generations are passing away when our ancient customs and traditions have not been properly documented. Cultural rediscovery and revival among our people has also become very important today in view of the massive cross cultural interactions taking place among Eggon and other ethnic nationalities which is gradually adulterating our values and language. An ethnic group that yields to this pressure easily loses its cultural heritage and by so doing, its identity. This ugly trend must be resisted by Eggon sons and daughters living today in order to reposition Eggon people for a greater tomorrow. The Eggon people are domiciled and indigenous to; and are the predominant tribe in Nasarawa state. They are found in all the Local Government Areas of the State in a sizeable population. Nasarawa state is located at the central part of Nigeria otherwise known as NorthCentral Nigeria. The Eggon people are also settled in different parts of Nigeria and overseas. They are mostly agrarian, and few decades ago went into trading, business and have great passion for Western education.
\end{abstract}

Keywords: Culture, Eggon people, society, soul of existence

\footnotetext{
*Research Scholar, Nigeria. email: dumbugala@gmail.com
} 


\section{INTRODUCTION}

History generally shapes the future. It helps to learn about the past; to understand the present; and to appreciate one's heritage. It enables people appreciate their traditions, achievements, beliefs; to broaden your perspective; and to acquire background for critical thinking. ${ }^{1}$ The history of the origin of the Eggon nation that are available do not provide details of her exact origin. Comprehensive studies of the origin of the Eggon nation using archeological, anthropological, carbon dating and genetic researches are needed to corroborate and give reliability of her origin. Some school of thoughts have it that Eggon ancestors sojourned through or from Ngazargamu in the present day Borno State of Nigeria and then moved away, and were part of the Kwararafa kingdom.

It was when Kwararafa was scattered that they crossed the river Benue at Ibi. It is also narrated that the Eggon people have affinity or connection with the Jukuns of Taraba state Nigeria; Tarok, Rukuba, Ngas of Plateau state Nigeria; and Migili, Rindire, Akye, Yeskwa and Buh from Nasarawa state Nigeria. There are also conflicting stories that the Eggon nation is part of the old Kwararafa Kingdom, while another version has it that the Eggon nation is unique and from the Benue-Congo extraction having the same history with the Tiv of Benue state Nigeria. ${ }^{2}$ This piece of history is not to delve into the historical origin of the Eggon nation, rather, its history of the Eggon Centralised Traditional Chieftaincy Institution.

\section{The Eggon Centralised Traditional Chieftaincy Institution}

The Eggon centralized chieftaincy institution was first established in 1919 with the appointment of Mr. Bashayi Yamusa as the first paramount leader of the Eggon nation by the British colonial administration. The appointment of Bashayi then was to serve the interests of the British colonial administration, hence did not represent the core interest of the Eggon nation. Eggon hitherto, had no supreme or central leadership, rather, had a well-structured leadership at clans and settlements levels known as the Chief Priest (which is referred to as Adang-Ashmu in Eggon language). Bashayi Yamusa was not an Eggon by tribe but Fulani from then Keffi Local Government Authority, but had maternal relationship with the Eggons. Though he was not Eggon by tribe, he was probably appointed because of his small background of the British colonial administrative system and for ease of communication and administration. He ruled for six years from 1919 to 1925 . He was removed in June 1925 for misrule and abuse of public office. His reign had both positive and negative impacts. During his reign some peace and order were achieved in Eggonland, thus, a grade B court was established to try all cases; a native system of administration was established; a native treasury was introduced; and a modern system of taxation was also introduced which brought the people into contact with Western civilization and modern economy.

On the other hand, Bashayi had some shortcomings during his reign. His reign was characterized by feudalism and to some extent he relied on a small cabal of advisers whom he brought from Keffi. He was repressive, exploitative and dictatorial and attempted to impose Islamic religion on the people which was resisted though few converted to the Islamic religion but held tight to their

1 Marvin Perry, A History of the World, Boston, USA. Houghton Miffin Company, 1986. Pp. 18, 19

2 PAGAN9JA (2013), The Eggon People - Culture, Aaira land Forum <nairaland.com/1299223/eggon-people> Accessed 5 February 2020. 
ancestral traditional religion which they believed was given to them by God. He became unpopular as an agent of the colonial Administrators because he was obliged to supply forced labour for the construction of the extension of the eastern Railway line. Bashayi and his Hausa and Fulani brothers, who were his close associates, did not integrate with the people adequately to command fraternity and general respect. In all fairness, Bashayi's leadership was not totally bad as he contributed immensely to the development of the Eggon people by integrating them to the wider world. However, his dictatorship, repressive attitudes among others contributed to his removal. Subsequent actions by the colonial administrators preceding his removal shown that the Colonial administration preferred an indigene to rule their people instead of a foreigner. ${ }^{3}$ Must note that the British colonial administration in those days could remove a person from an appointed office if the office holder seems to be working contrary to their interests, or has fallen out of favour, and not necessarily for lack of competence, misrule or abuse of office.

After Bashayi's removal, the British administration selected Mr. Alumbugu Otsahwe as the second Eggon centralized leader, and the first indigenous Eggon Chief who ruled from 1926 to 1942. Chief. Mr. Otsahwe was not literate but was a charismatic leader who was well respected, and represented the Eggon tradition and culture. During Otsahwe's rule, he worked hard and united the three major Eggon clans (i.e. Eggon-Anzo, Eggon -Ero and Eggon-Eholo). This he did by choosing six members, two each from the three sub-ethnic groups to represent the interest of their diverse communities in the arbitration court. He believed in traditional religion to the extent that he used traditional means and rituals to settle and dispense justice among his people, and worked immensely toward protecting the Eggon traditional religion and culture. He projected the Eggon nation far and wide in the then northern Nigeria and the world at large.

Otsahwe was extremely traditional thus frustrating the efforts of the Christian Missionaries in Eggon land. He opposed Westernization of the society because of his nationalism for the Eggon nation. He opposed British administration and viewed it as foreign intervention which he found unacceptable. Because of non-cooperation with the British administration, he became unpopular to the British administration and was accuse of misrule and maladministration and his reign was terminated on 1 September 1942, and was exile to Lafia where he stayed in Azuba village until his death.

In September 1942 Mr. Abimiku Alumbugu, the son of the exiled Chief was appointed to act as a caretaker Chief. He also was remove from office in June 1943, after a brief period of about 9 Months of leadership because of his inefficiency. There was a 10-year leadership vacuum from 1943 to 1953 because the Eggon chieftaincy institution had series of crises, and efforts by the British administration to use democratic methods to select a Chief for the institution were frustrated or not agreed by the non-compromising contestants from the three sub-ethnic groups. When after further efforts in 1944 it was not possible to appoint a new Chief, Mr. Philip, the administrative officer in charge of Akwanga then introduced a district administration based on the three sub-ethnic groups to take charge of Eggonland. Mr. Alu Agbi was appointed the district head of Eggon-Eholo; Mr. Angbolo Alafu Umme for Eggon-Ero and Mr. Angibi Ekwabala for Eggon-Anzo. The three district heads worked towards the maintenance of unity, peace and order in Eggonland. ${ }^{4}$ The customary court, which was the only court in Eggon land at

\footnotetext{
${ }^{3}$ Mair LN, New Nations, London. 1963, P6.

${ }^{4}$ Op.Cit, Mair. P.2
} 
that time, was to alternate among the three districts with joint-sittings under the three district heads. ${ }^{5}$

Thereafter, a new search for an Eggon traditional leader began with the following prominent contestants: Mr. Alhaji Abdullahi Idde the former Treasurer of Akwanga Local Government Authority, Mr. Anmwre Ekutsa and Alhaji Adamu Musa Galle. Alhaji Abdullahi Idde from the Anzo sub-ethnic group and a primary school leaver, an accountant, and outspoken man with good leadership qualities won the support of the British administration, and on 2 October 1953, appointed and became the third indigenous leader of Eggon as Aren Eggon. He ruled for 28 years and died on 6 May1981. Alhaji Abdullahi Idde encouraged the formation of the Eggon Cultural and Development Association (ECDA) which came to fruition in 1972. It was during Idde's reign that the system of kingmakers was introduce and made the Eggon selection method democratic instead of imperial family or by ancestry. He was a man with wide range of experience who promoted and projected the Eggon culture, tradition and unity.

After Abdullahi Idde's death, Umbugala Alaku Envulu Akpoya, Aren Ezen acted as Aren Eggon for about two months. Mr. Bala Abaine Angbazo was the first elected by democratic means by kingmakers, which took place on the 11 July 1981 with a 1-vote margin after a tie. The election of the Aren Eggon was from the list of Eight (8) candidates that contested for the chair in 1981. Among the other contestants were Late Alhaji Adamu Musa Galle, Chief Jatau Salame Anga, Late Abdullahi Angibi, Late Hon Esla Samson Alu, Alhaji Usman Angbolo, Alhaji Ali Idde, and Alhaji Idrisu Mohammed Gama. After the election of Bala Abaine Angbazo as the paramount traditional leader of the Eggon nation as Aren Eggon, the chair was later upgraded to First Class status in 1982.

The 22 electoral college consist of the person holding the following offices, namely:

$\begin{aligned} \text { i. } & \text { Aren Alizaga } \\ \text { ii. } & \text { Aren Bakyano } \\ \text { iii. } & \text { Aren Umme } \\ \text { iv. } & \text { Aren Arugbadu } \\ \text { v. } & \text { Aren Galle } \\ \text { vi. } & \text { Aren Alogani } \\ \text { vii. } & \text { Aren Ogbagi } \\ \text { viii. } & \text { Aren Agunji } \\ \text { ix. } & \text { Aren Wakama } \\ \text { x. } & \text { Aren Ezen } \\ \text { xi. } & \text { Aren Arikpa } \\ \text { xii. } & \text { Aren Ogba } \\ \text { xiii. } & \text { Aren Wana } \\ \text { xiv. } & \text { Aren Angbashu } \\ \text { xv. } & \text { Aren Lizzin Keffi (Aren Odzi) } \\ \text { xvi. } & \text { Aren Wulko (Aren Ende) } \\ \text { xvii. } & \text { Aren Alushi } \\ & \end{aligned}$

${ }^{5}$ Dudley DJ, Parties and Polities in Northern Nigeria: Traditional, Social and Political Organization, London, 1963. P5. 


$$
\begin{aligned}
\text { xviii. } & \text { Aren Ikka } \\
\text { xix. } & \text { Aren Ginda } \\
\text { xx. } & \text { Aren Wangibi } \\
\text { xxi. } & \text { Aren Wolon } \\
\text { xxii. } & \text { Aren Lambaga }
\end{aligned}
$$

Also the 22 kingmakers from the 22 Clans who formed the Electoral College during the election of Bala Abaine Angbazo were:
1. Aren Ogba
2. Aren Alogani
3. Aren Wakama
4. Aren Agunji
5. Aren Umme
6. Aren Ezen
7. Arem Wangibi
8. Aren Lizzin Keffi (Aren (Odzi)
9. Aren Ekka
10. Aren Ginda
11. Aren Alushi
12. Aren Wulko (Aren Ende)
13. Aren Alizaga
14. Aren Lambaga
15. Aren Arikpa
16. Aren Wolon
17. Aren Ogbagi
18. Aren Galle
19. Aren Bakyono
20. Aren Arugbadu
21. Aren Wana
22. Aren Angbashru
Mr. Ambaga Affiku
Mallam Yusuf Dauda
Mr. Anzume Umbugadu
Mallam Ali Elle Gambo
Mr. Angyo Audu
Umbugala Alaku Envulu Akpoya
Mr. Otsona Kuje
Mr. Agu Envulanza
Mr. Alumbugu Azgabogo
Mr. Tabe Angbo
Mr. Peter Nangba
Mr. Ende Tsaku
Mr. Azza Angbu
Mr. Ala Kuson
Mr. Male Najo
Mr. Avre Ajege
Mallam Haruna Atta
Mallam Adamu Epka
Mallam Mohammadu Gama
Mr. Audu Egga
Mr. Akyen Namo
Mallam Aliyu Musa Jatau

The list above is not presented in any form of seniority.

The scores of the Election conducted on 11 July 1981:

- Bala Abaine Angbazo

- Late Alhaji Adamu Musa Galle

- Late Esla Samson Alu

- Ali Idde

- Late Alhaji Abdullahi Angibi
7 votes

7 votes

5 votes

2 votes

\footnotetext{
${ }^{6}$ Plateau State of Nigeria Gazette (1981), Plateau State Notice No. 70 No. 13, Vol. 6. P. S. Legal Notice No. 6 of 1981-The Chiefs (Appointment and Deposition) Law (Cap. 20) - (Appointment of Aren Eggon Order, 1981) Printed and Published by the Government Printer, Jos.
} 
- Alhaji Idrisu Mohammed Gama Nil

- Mr. Jatau Salame Anga Nil

- Alhaji Usman Angbolo $\quad \mathrm{Nil}^{7}$

\section{The Tie and How It Was Broken}

Initially, there was a tie of seven votes between Bala Abaine Angbazo and Late Alhaji Adamu Musa Galle in the first round of the election, as only 21 kingmakers (Clans) voted to the exclusion of Aren Ezzen (Umbugala Alaku Envulu Akpoya) who was then the leader of the 22 Clans' head (Aren Mo Aren). During the period under review, a clan head i.e Aren Mo Aren was not supposed to vote; hence, he did not vote in the first round of the election. It was then decided that since there was a tie and the Clans head was next to the late Aren Eggon Late Alhaji Abdullahi Idde, he should cast his vote to break the tie and decide a winner. Note that Aren Ezzen was neither a Christian nor a Muslim. However, he believed strongly in traditional religion. Before Aren Ezzen who then doubled as Aren Mo Aren to cast his vote to decide the winner, he stood up and made a heart touching speech. Though a detail of the speech was not narrated to us, the summary was thus:

'Alhaji Adamu Musa is my best and longtime friend but never associated much with the Eggon people, and at a time, even claimed to be Hausa by tribe. I know he is not. He only added Galle to his name when he was contesting for the position of Aren Eggon otherwise he was only known as Alhaji Adamu Musa (now Alhaji Adamu Musa Galle). I am skeptical if his loyalty to the Eggon nation will be total. For Bala Abaine Angbazo, I don't know much about him. I only heard about him as a Philanthropist and a business man. I don't have any close relationship with him...'

It was actually after this speech that caused Aren Ezzen to cast his vote in favour of Bala Abaine Angbazo which changed the votes to 8 for Bala Abaine Angbazo and 7 for Alhaji Adamu Musa Galle. Umbugala did not look at his close relationship with Alhaji Adamu Musa Galle but his conscience and the future of the Eggon nation as a whole.

\section{The Democratic Method of Selecting Aren Eggon}

The new and democratic means of electing the Aren Eggon referred to as "Electoral College" by THE CHIEFS (APPOINTMENT AND DISPOSITION) LAW (CAP 20) - (APPOINTMENT OF AREN EGGON) ORDER, 1981 first came into force on the 8 May 1981. It provides that 'the Aren Eggon shall be elected from and among the adult males of Eggon tribe. There shall be established an electoral college for the purpose of the selection of the Aren Eggon which shall consist of the persons holding the following offices, namely (Please see page 6 and 7 for the list). Section 5 of the gazette states that 'whenever the office of the Aren Eggon shall be vacant the Local Government Council shall summon a meeting within the Local Government Area of the Electoral College after giving notice of not less than 7 days of its intention to summon such a meeting'.

\footnotetext{
${ }^{7}$ Eggon News Vol. 4 No. 2, September 2007. Pp. 1, 2, 4. See also: Eggon News Vol. 4 No. 3, October, 2007. p 9; Alu, C. (2009), Towards a Great Eggon Nation: Retracting The Steps of Our Ancestor Published by Eggon News Vol. 6 No. 4, October 2009. p10.
} 
The Gazette stresses further:

1. The Secretary to the Local Government and a representative of the Local Government shall be in attendance as observers

2. A person appointed by the Governor shall be in attendance as the Presiding Officer of such meeting.

3. Fourteen members of the Electoral College shall constitute a quorum at such meeting

4. The Presiding Officer shall issue nomination papers to each member of the Electoral College at the meeting and shall call for nomination of candidates

5. Nominations of candidates shall be to the Presiding Officer at the meeting

6. No member of the Electoral College shall nominate himself

7. If only one person is nominated, such person shall be deemed to be selected as the Aren Eggon, subject to the approval of the Governor after consultation with Council of Chiefs

8. If a member of the Electoral College is nominated and agrees to stand for election, he loses his right to vote and shall vacate the Electoral College

9. If a member of the Electoral College loses his voting right he shall not be replaced by another person and shall vacate the Electoral College that is, no one shall be brought in to represent him at the Electoral College to take his position and vote

10. In the event of first and second tie, there shall be a fresh ballot held after an interval of seven days in each case in accordance with Sub-section (1) of Section 5 of the gazette for the candidates who received the largest equal votes 8

11. In the case of up to third tie, the Presiding Officer shall forthwith decide between the candidates with the largest and equal number of votes by lot, and the candidate on whom the lot falls shall be deemed to be selected to be Aren Eggon subject to the approval of the Governor after consultation with the Council of Chiefs.

The gazette further states that the Presiding Officer shall communicate the result of the election in writing within two days of such selection to the Governor for approval. ${ }^{9}$ This is a concise process of the selection of Aren Eggon.

The Office Holders of the Eggon Centralized Traditional Chieftaincy Institution so far.

1. HRH Bashayi Yamusa

2. HRH. Alumbugu Otsahwe

3. HRH. Abimiku Aluombugu

4. HRH. Alhaji Abdullahi Idde

5. HRH. Bala Abaine Angbazo

$\begin{array}{ll}- & 1919-1925 \\ - & 1926-1942 \\ - & \text { September } 1942-\text { June } 1943 \\ - & \text { 2October } 1953-1981 \\ - & \text { 11 July 1981 till Date. }\end{array}$

- $\quad 1919-1925$

- $1926-1942$

- $\quad$ September 1942 - June 1943

- $\quad 11$ July 1981 till Date.

\section{Corroborated Oral History}

The clan name Lizzin Keffi is not the true name of the clan herein referred to. The real and true clan name is Odzi. The name was mutilated or intentionally changed by the then regular foreign

\footnotetext{
8 Ayimom. An Eggon Magazine of the National Union of Eggon Students (NUES), University of Jos Vol. 1. (1986) Pp. 17 -20, 24 - 31. See also Plateau State of Nigeria Gazette (1981) at Page 5; Government Printer (1983), Programed for the Installation of His Royal Highness The Aren Eggon, Mr. Bala Abaine Angbazo; and Benue Plateau Edict No. 1 (1969)

9 Ibid.
} 
traders who came from the then Keffi District to Odzi main market for the buying of foodstuff. The government then instead of using the true name of the indigenous people used the name called and used by the foreigners who were more influential. The Chieftaincy title should be known and called Aren Odzi and not Aren Lizzin Keffi which is not a true reflection of the aborigines. The clan name Ezen is just the problem of spelling error or the spelling opinion of the writer. The real spelling is Ezzen, and the Chieftaincy title should be known and called Aren Ezzen and not Aren Ezen. The Chieftaincy title Aren Wulko seems misleading. Wulko is a name of an area land mass and not a clan. The real clan name is Ende, hence, the Chieftaincy title should be called and referred to as Aren Ende and not Aren Wulko.

\section{CONCLUSION}

During the century of the Eggon centralized traditional leadership institution 1919 to date, there have been 5 traditional leaders. The Eggon 'recognized' centralized traditional system has also undergone some few reforms - from direct appointment of a traditional leader by the British Colonial administrative officer to the democratic system of selection which first commenced from 8 May 1981. This brought into the first democratically elected leadership of Aren Eggon, Bala Abaine Angbazo who on 11 July 1981 won by a 1 vote margin after a tie with Alhaji Adamu Musa Galle. Before the Eggon centralize traditional institution was put in place by the British administration in 1919, the Eggon had a long history of well-structured autonomous 'clans' and traditional system called Adang-Ashmu (which mean Chief Priest or Spiritual Leader). No wonder, the Eggon people could not conquered by the Othman Dan Fodiyo, led to Jihad because they easily mobilized themselves and stood against the invaders. The centralized Eggon traditional system brought the different autonomous clans leadership into a single paramount institution for the entire Eggon nation in 1919 but retain Aren leadership at clans' level who now forms the 22 kingmakers as listed above. 


\section{REFERENCES}

Ayimom, An Eggon Magazine of the National Union of Eggon Students (NUES), Vol. 1 University of Jos , 1986

Dudley D. J. Parties and Polities in Northern Nigeria: Traditional, Social and Political Organization, London: 1963

Eggon News Vol. 4 No. 2, September 2007. Pp. 1, 2, 4. See also Eggon News Vol. 4 No. 3, October, 2007. p 9; Alu C. (2009), Towards a Great Eggon Nation: Retracting The Steps of Our Ancestor, Published by Eggon News Vol. 6 No. 4, October, 2009. p10

Mair L N, New Nations, London: 1963

Marvin Perry, et al, A History of the World, Boston, USA: Houghton Miffin Company, 1986

PAGAN9JA The Eggon People-Culture, Nairaland Forum: 2013 <nairaland.com/1299223/eggon-people>.

Plateau State of Nigeria Gazette (1981), Plateau State Notice No. 70 No. 13, Vol. 6. P. S. Legal Notice No. 6 of 1981-The Chiefs (Appointment and Deposition) Law (Cap. 20) (Appointment of Aren Eggon Order, 1981, Printed and Published by the Government Printer, Jos. 